\title{
PENGARUH PEMBERIAN ZnSO 4 $1 \%$ TOPIKAL TERHADAP EKSPRESI MMP-9 DAN JUMLAH FIBROBLAS PADA PENYEMBUHAN ULKUS TRAUMATIKUS TIKUS WISTAR DIABETES MELITUS
}

\author{
Lukman Hakim Hidayat*, Priyo Hadi**, Desiana Radithia** \\ * Departemen Ilmu Penyakit Mulut Fakultas Kedokteran Gigi Universitas Brawijaya \\ **Departemen Ilmu Penyakit Mulut Fakultas Kedokteran Gigi Universitas Airlangga \\ Korespondensi: Lukman Hakim Hidayat, E-mail: lukmandentist@gmail.com
}

\begin{abstract}
ABSTRAK
Diabetes mellitus adalah penyakit yang berdampak pada proses penyembuhan luka di dalam mulut. Pada penderita diabetes melitus, aktifitas prolifrasi fibroblast menurun dan aktifitas enzim kolagenese serta MMP-9 meningkat, sehingga penyembuhan ulserasi pada rongga mulut akan menjadi lebih lama. Zinc sulfat merupakan mineral yang dapat meningkatkan sinyal antar sel, proliferasi komponen penyembuhan, serta migrasi komponen pada tahapan penyembuhan. Tujuan: untuk menganalisis pengaruh pemberian zinc sulfat $1 \%$ secara topikal pada ekspresi MMP-9 dan jumlah sel fibroblas jaringan mukosa mulut hewan coba pada kondisi diabetes mellitus, yang mengalami ulkus traumatikus. Metode: Pada penelitian ini hewan coba (48 ekor tikus wistar) berusia 2-3 bulan dan berat badan 150-200 gram, dibagi menjadi empat grup. Untuk mendapatkan tikus diabetes, maka subjek diinduksi dengan streptozotocin $(30 \mathrm{mg})$ yang dilarutkan dalam 1,33 ml buffer (asam sitrate). Untuk membuat ulser pada jaringan mukosa mulut, maka dilakukan dengan menempelkan burniser panas selama 10 detik pada mukosa bibir subjek. Pada setiap periode ekperimen (hari ke-5 dan ke-7) dilakukan pengambilan jaringan mukosa, dan dilanjutkan dengan pembuatan preparat histologi. Pada preparat histologi digunakan pengecatan HE untuk mengidentifikasi dan menghitung jumlah fibroblast, sedangakan IHS untuk mengidentifikasi dan menghitung ekspresi MMP9. Metoda statistik one-way Anova digunakan untuk analisis perbandingan antara grup perlakuan dan grup kontrol. Signifikansi didasarkan pada nilai $p<0.05$. Hasil: Pemberian zinc sulfat $1 \%$ secara topikal pada ulkus traumtikus pada tikus diabetes mengakibatkan terjadi peningkatkan jumlah fibroblas $(p<0,05)$ dan menurunkan ekspresi MMP-9 $(p<0,05)$ yang diamati pada setiap periode eksperimen yang ditetapkan dalam penelitian ini. Kesimpulan: Zinc sulfat $1 \%$ dapat mempercepat proses penyembuhan ulkus traumatikus pada hewan coba dengan kondisi diabetes mellitus.
\end{abstract}

Kata kunci : diabetes melitus, ulkus traumatikus, zinc sulfat , MMP-9, fibroblas. 


\title{
EFFECT OF TOPICAL ZnSO4 1\% ON THE MMP-9 EXPRESSIONS AND THE NUMBER OF FIBROBLAST IN TRAUMATIC ULCER HEALING OF DIABETES MELITUS WISTAR RATS
}

\begin{abstract}
Diabetes mellitus is the worldwide metabolic disease and lead to higher mortality in every years around the globe. This conditions lead to increased intensity and duration of inflammation, thus impair the healing process. Hence, the ulceration as the most common oral disease becomes harder and longer to heals. Zinc Sulphate as the trace elements has been used for many years in wound treatment therapy. This mineral has an important role in healing phases, by inducing the signalling, proliferations and migrations of the healing phases components. Objectives: The aim of this research, is to analyze the effect of the topical zinc sulphate $1 \%$ in MMP-9 expressions and fibroblast amount in mucosal tissue of diabetic wistar rat. Methods: This post-test only control group design study used 58 Wistar rat of 2-3 month, 150-200 gram in weight. The animals were divided into four groups, normal, diabetes, normal + $\mathrm{ZnSO}_{4}$ and diabetes $+\mathrm{ZnSO}_{4}$. Rats were induced by streptozotocin $30 \mathrm{mg}$ diluted in $1,33 \mathrm{ml}$ buffer citrates to create diabetic condition. After experiment time periods (5 and 7days) the mucosal tissues specimens were prepared and stained by using HE to observe fibroblasts morphology, and immunohistochemistry method was used to analyse MMP-9 expressions, and the results were analyzed using one-way Anova. Result: The uses of zinc sulphate 1\% therapy in traumatic ulceration, decreased the MMP-9 expressions and increased the fibroblast number in diabetic conditions, compare to those in control groups, the difference was significantly difference $(p<0,05)$. Conclusion: The adding of Topical ZnSO4 1\% in ulceration treatment is accelearing tissue healing process in diabetic mice
\end{abstract}

Key words: diabetes melitus, traumatic ulcer, zinc sulphate, MMP-9, fibroblast.

\section{PENDAHULUAN}

Pada tahun 2012, International Diabetes Federation (IDF) mengungkap DM di seluruh dunia mencapai 371 juta jiwa dan penderita di Indonesia mencapai 7,6 juta. ${ }^{1,2}$ Berdasarkan American Diabetes Association (ADA), Perkumpulan Endokrinologi Indonesia (Perkeni) mendefinisikan DM sebagai suatu kelompok penyakit metabolik dengan karakteristik hiperglikemia yang terjadi karena kelainan sekresi insulin, kerja insulin atau keduanya. 3,4 Hiperglikemia yang kronis, menyebabkan proses penyembuhan yang lambat akibat peningkatan sitokin proinflamasi, advanced glycation end-products (AGE's) dan reactive oxygen species (ROS). Pada penderita DM, penyembuhan yang lambat dapat dijumpai pada ulkus rongga mulut. ${ }^{5}$ Penelitian sebelumnya 
mengungkapkan, bahwa kondisi DM akan diikuti oleh adanya hiperzincuria dan hipozincemia yang menyebabkan terjadinya defisiensi Zinc pada penderita DM. Defisiensi Zinc akan mempengaruhi peningkatan advanced glycation end-products (AGEs), dan berakibat meningkatnya oxidative stress yang merupakan faktor terhambatnya proses penyembuhan. 6,7

Pada proses penyembuhan sel dominan yang berperan penting adalah fibroblast karena bertanggung jawab pada pembentukan dan pemelihara jaringan ikat (connective tissues) mempunyai tiga tahapan penting, yaitu fase inflamasi, fase proliferasi dan fase remodeling. ${ }^{8}$ Fibroblas merupakan faktor kunci pada fase kedua dan merupakan sel dominan. Komponen fibrous dari jaringan ikat, akan mengalami peningkatan proliferasi dan migrasi dengan pemberian mineral ini. 8,9

Pada proses penyembuhan yang normal, keseimbangan antara matriks metaloproteinase (MMP) dan tissues inhibitor matrixmetalloproteinases (TIMP) akan tercapai. Enzim ini mempunyai peran yang sangat penting dalam penyembuhan. Secara fisiologis, MMP memainkan peran penting dalam mendegradasi extracellular matrix (ECM) dan pembentukan kembali ECM. MMP juga berperan pada masa pertumbuhan dan perkembangan embrional, mempengaruhi proses seluler seperti proliferasi, regulasi Growth Factors (GF), diferensiasi, migrasi, adesi dan regenerasi jaringan. ${ }^{10,11,12}$ Pada penderita DM, level glukosa darah yang tinggi menyebabkan peningkatan MMP-9 serta menurunkan ekspresi TIMP. Meningkatnya MMP9 mempengaruhi jumlah sitokin proinflamatori, misalnya IL-8 yang akan meningkatkan kemoatraktan terhadap netrofil, mekanisme ini meyebabkan lambatnya proses penyembuhan pada kondisi DM. ${ }^{13}$

Bahan campuran $\mathrm{Zn}$ dengan bahan campuran sulfat, klorida, glukonat, oksida dan stearate digunakan sebagai selain bahan campur senyawa $Z n$, juga memiliki fungsi dalam mengurangi efek inhibitor $Z n$ terhadap absorbsi besi, dan mempertahankan stabilitas Zn. ${ }^{14}$ Zinc Sulfat $\left(\mathrm{ZnSO}_{4}\right)$ banyak digunakan untuk mengobati luka dengan meningkatkan pembentukan jaringan granulasi, re-epitelisasi, sebagai anti inflamasi, meningkatkan proses fagositosis, meregulasi faktor pertumbuhan seperti vascular endothelial growth factors (VEGF), fibroblast growth factors (FGF) dan insulin like growth factors (IGF-1). Zn meningkatkan migrasi keratinosit dan fibroblas serta mengaktifkan sel endotel. ${ }^{15}$ Mineral ini menginduksi sub-unit integrin yang berperan dalam pergerakan keratinosit.

Penelitian tentang $\mathrm{ZnSO}_{4} 1 \%$, secara topikal sebelumnya dilakukan pada luka bekas pencabutan gigi pada tikus wistar, dan telah tebukti secara klinis mempunyai peran dalam mempercepat proses penyembuhannya. ${ }^{16}$ Namun pengaruh dan mekanisme kerja dari $\mathrm{ZnSO}_{4} 1 \%$ secara topikal terhadap jumlah fibroblas dan ekspresi jumlah MMP-9, pada proses penyembuhan ulkus traumatikus pada kondisi DM, belum pernah dibuktikan sebelumnya.

\section{METODE}

Penelitian ini merupakan penelitian eksperimental laboratoris dengan menggunakan 
rancangan penelitian Post Test Only Control Group Design. Penelitian dilakukan di Laboratorium Biokimia Fakultas Kedokteran Universitas Airlangga dan Fakultas Kedokteran Universitas Brawijaya pada bulan oktober hingga desember 2014. Subjek penelitian menggunakan hewan coba tikus Wistar yang dikelompokkan menjadi tikus normal dan tikus diabetes yang telah dibuat ulkus pada mukosa bibir bawah, dengan menggunakan burnisher panas yang ditempelkan di mukosa bibir selama 10 detik Selanjutnya, terhadap masing-masing kelompok tikus tersebut dibagi menjadi 2 (dua) subkelompok, untuk diberi gel Zinc Sulfat $1 \%$ $\left(\mathrm{ZnSO}_{4} \quad 1 \%\right)$ dan gel carboxymethylcelluloses (CMC-Na) secara topikal. Dengan demikian, didapatkan empat kelompok tikus, yaitu 2 (dua) kelompok tikus normal yang diaplikasikan gel CMC-Na dan yang diaplikasikan gel $^{\mathrm{ZnSO}_{4}} 1 \%$, serta 2 (dua) kelompok tikus diabetes yang diaplikasikan ge/CMC-Na, dan yang diaplikasikan ge/ $\mathrm{ZnSO}_{4} 1 \%$.

Sebelum di induksi dengan STZ, subjek dipuasakan selama empat jam sebelum untuk mengosongkan lambung dan mengurangi resiko aspirasi. STZ yang dibutuhkan, sebanyak $150 \mathrm{mg} / \mathrm{kg}$ BB yang dilarutkan dengan konsentrasi STZ $22,5 \mathrm{mg} / \mathrm{ml}$ pada larutan buffer sitrat. Larutan STZ dimasukkan ke dalam tabung yang terbungkus alumunium foil. Larutan STZ dipindahkan ke dalam syringe $1 \mathrm{ml}$, dan didiamkam selama 30-60 detik, sebelum induksi. Larutan STZ diinjeksikan melalui intraperitoneal sesuai dengan kebutuhan dosis per ekor. Dalam peneltian ini, induksi STZ hanya dilakukan sebanyak satu kali. Selanjutnya tikus dikorbankan pada hari ke-5 dan ke-7. Dilakukan insisi jaringan pada bibir bawah dan pemrosesan jaringan, untuk dibuatkan sediaan histologi. Berikutnya dilakukan penghitungan sel fibroblas serta ekspresi MMP-9, menggunakan pulasan HE. Data yang diperoleh dianalisis dengan ANOVA dan dilanjutkan uji Tukey HSD.

\section{HASIL}

Pada pengamatan kelompok kontrol dan perlakuan hari ke-5, pada jaringan mukosa tikus, tampak sel radang yang didominasi oleh makrofag dan netrofil dengan jumlah sedikit. Fibroblas sebagai sel pembentuk jaringan ikat yang immature, terlihat mulai muncul dan berproliferasi. Setelah diberi perlakuan dengan bahan uji (ZnSO4 1\%), tampak jumlah kedua sel ini meningkat secara signifikan dibandingkan dengan kelompok kontrol (Gambar 1).

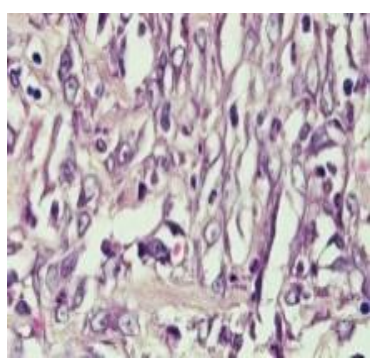

A

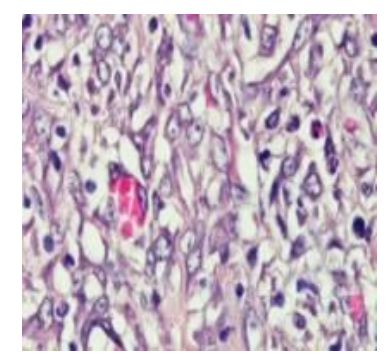

B
Gambar 2. Ekspresi Fibroblast Hari ke-5 (pembesaran 1000x)

Ket: A: kelompok normal B: kelompok perlakuan Demikian pula, pada periode ini pengamatan terhadap ekpresi MMP-9, menunjukan, bahwa setelah diberi perlakuan bahan uji, ekspresi MMP-9, yang tampak sebagai warna coklat jumlahnya menurun pada kelompok perlakuan dibandingkan dengan kelompok kontrol (gambar 2). 


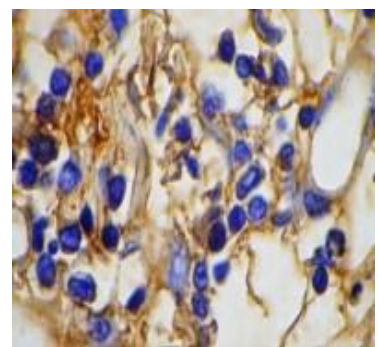

A

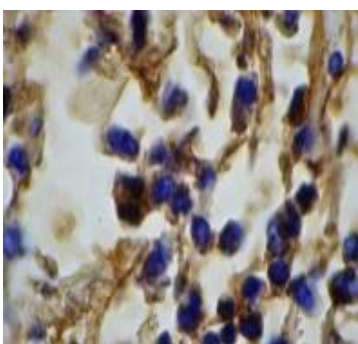

B
Gambar 2. Ekspresi MMP-9 Hari ke-5

(pembesaran 1000x)

Ket: A: kelompok normal; B: kelompok perlakuan

Pengamatan penyembuhan jaringan pada hari ke-7, gambaran histopatologis sel radang mulai berkurang dan fibroblas merupakan sel dominan. Fibroblas pada kedua kelompok tampak mulai mature dan menyatu dengan serabut kolagen yang disebut sebagai fibrosit. ${ }^{17}$ Tampak pula adanya pembentukan jaringan ikatmuda dan morfologi fibrosit yang memanjang, mengikuti bentuk serabut kolagen, diikuti dengan proses vaskularisasi.

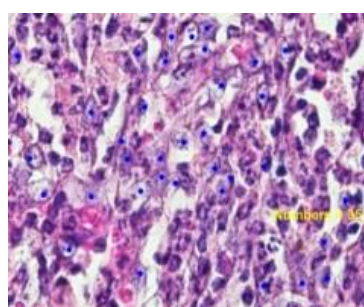

A

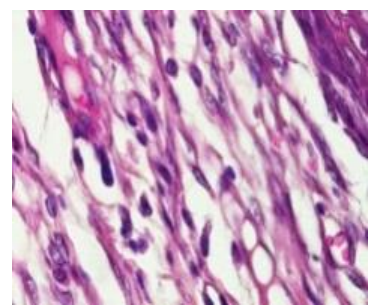

B
Gambar 2. Ekspresi MMP-9 Hari ke-5

(pembesaran 1000x)

Ket: A: kelompok normal; B: kelompok perlakuan

Jumlah fibroblast lebih sering ditemukan pada kelompok perlakuan, dibandingkan dengan kelompok kontrol (Anova,p<0.05) (gambar 3). Pada hari ke-7 ini, frekuensi protein MMP-9 lebih sering ditemukan pada kelompok kontrol dibandingkan dengan kelompok perlakuan (Anova, p< 0.005) (gambar 4). Demikian pula, uji
HSD menunjukkan adanya perbedaan bermakna $(p<0,05)$ antar semua kelompok.

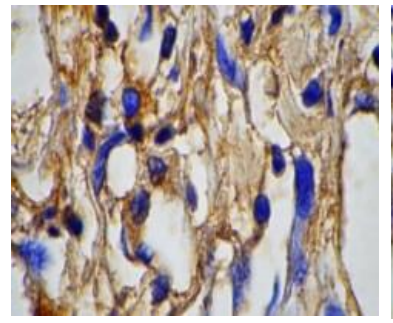

A

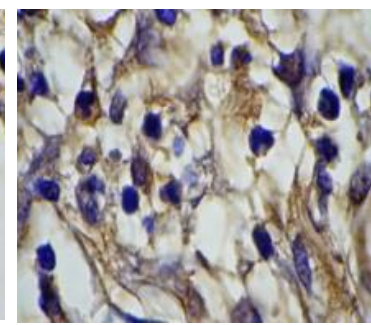

B
Gambar 4. Ekspresi MMP-9 Hari Ke-7

(pembesaran 1000x)

Ket: A: kelompok normal; B: kelompok perlakuan

\section{PEMBAHASAN}

Proses penyembuhan ulkus traumatikus, melalui beberapa tahapan penyembuhan berfungsi memperbaiki kontinuitas jaringan dan merupakan hasil dari interaksi sel platelet, netrofil, makrofag, fibroblas, sel endotel, dan keratinosit termasuk juga komponen dari matriks ekstraseluler (ECM). ${ }^{18,19}$ Fibroblas dan matriks metaloproteinase (MMP-9) merupakan salah satu komponen penting dalam rangkaian proses penyembuhan.

Pada penelitian ini, maturase fibroblast diamati pada hari ke-5 dan ke-7. Fibroblas memproduksi kolagen, glikosaminoglikan, serat elastin dan glikoprotein yang membentuk matriks ekstraseluler. ${ }^{20}$ Fibrosit sebagai bentuk inaktif disekitar jaringan yang rusak, akan diinduksi oleh makrofag menjadi fibroblas pada proses penyembuhan. Fibroblas terakumulasi di daerah tepi ulkus melalui angiogenesis antara 2 sampai 5 hari pasca terjadi kerusakan. Jumlah fibroblas mencapai puncaknya sekitar 1 minggu pasca 
terjadi ulkus dan merupakan sel dominan pada minggu pertama fase penyembuhan. ${ }^{21,22}$

Pada DM, jumlah fibroblas yang menuju ke daerah ulkus akan berkurang, hal ini disebabkan karena jumlah fibroblas yang mengalami apoptosis meningkat yang disebakan oleh bertambahnya jumlah sitokin proinflamatori, advanced glycation end-products (AGE's) dan reactive oxygen species (ROS), yang meningkat pada kondisi DM. Keadaan ini disebabkan oleh peningkatan kadar glukosa darah yang tinggi, yang mempengaruhi perubahan Adenosine Triphosphate (ATP) dan aktivasi caspade $3 .{ }^{23}$

Sedangkan MMP-9 yang merupakan bagian dari famili gelatinase adalah enzim yang berperan penting dalam proses pembentukan ECM. MMP-9 dapat disekresikan oleh makrofag dan fibroblas selama proses penyembuhan. Peran utama enzim ini adalah untuk mendegradasi matriks dan jaringan nekrosis, serta bakteri infektif pada tahap awal penyembuhan, untuk kemudian dipersiapkan dalam tahap selanjutnya. ${ }^{24,25}$

Pada tahap proliferasi dan remodeling jaringan, MMP-9 berperan menyiapkan matriks yang menjadi jembatan antar tepi ulkus, agar fibroblas dan komponen lain dapat bermigrasi menuju daerah ulkus. Pada kondisi DM, ekspresi MMP-9 sebagai bagian dari tahap inflamasi akan tetap tinggi, sebagai akibat dari tahapan inflamasi yang berlangsung lama, sehingga aktivitas proteinase dan degradasi jaringan akan tetap berlangsung. Hal ini akan menyebabkan terhambatnya penyembuhan ulkus. ${ }^{26}$ Peran $\mathrm{ZnSO}_{4}$ dalam penelitian ini adalah mempercepat proses penyembuhan luka, seperti terlihat dalam penelitian ini, pemberian ZnSO4 1\%, menurunkan ekspresi MMP-9 pada tikus Wistar dengan kondisi DM. Ion pada $\mathrm{ZnSO}_{4}$ akan memicu gugus katalitik pada MMP-9 yang memiliki reseptor untuk $\mathrm{Zn}$ (zinc dependent) dalam mengurangi aktivitas proteinase bila matriks sudah mencukupi untuk fibroblas dapat bermigrasi dan berproliferasi ke daerah ulkus. ${ }^{27}$

Pada level molekuler dan seluler, Zn juga terlibat dalam sintesis insulin, sekresi dan signaling, oleh karena itu Zn memiliki pengaruh terhadap aksi dan fungsi insulin di dalam proses metabolism. Zn juga bekerja sebagai kofaktor pada aktivitas transkripsi DNA dan dalam aktivitas enzimatik, termasuk di dalamnya adalah aktivitas MMP, sehingga aktivitas debridemen dan migrasi keratinosit bertambah selama proses penyembuhan. ${ }^{28}$ Selain itu, mineral ini juga sebagai kofaktor yang memberikan perlindungan sel terhadap reactive oxigen species (ROS) demikian juga terhadap peptida bakteri yang bersifat racun, melalui aktivitas anti oksidannya terutama oleh cysteine-rich metallothioneins (MT) dan superoxide dismutase yang mengubah superoksida menjadi oksigen dan peroksida sehingga memilki aktivitas anti oksidan yang kuat.

Hal yang tidak kalah penting adalah fungsi $\mathrm{Zn}$ sebagai signalling component yang mempengaruhi faktor pertumbuhan dalam menginduksi proliferasi dan diferensiasi sel, termasuk fibroblas dan sel endotel. Zinc juga berperan dalam menyediakan energi metabolik yang diperlukan sel untuk bermigrasi ke daerah ulkus dalam proses penyembuhan melalui 
ekspresi integrin yaitu suatu protein adhesi yang penting untuk re-epitelisasi jaringan. ${ }^{29}$

Proses re-epitelisasi dengan migrasi dan proliferasi fibroblas pada mukosa mempunyai peran penting dalam proses penyembuhan yang normal. Pada penderita DM, terjadi penurunan produksi faktor pertumbuhan ( growth factor). ${ }^{30,31}$ Ini terlihat pada hasil pengamatan hari ke 5, dimana fibroblas mulai bertambah jumlahnya dan menyebar pada kelompok perlakuan dibandingkan kelompok kontrol. Pada hari ke-7, secara terlihat jumlah fibroblas mengalami peningkatan rata-rata pada kelompok perlakuan dibandingkan kelompok kontrol pada dimana fibroblas menyebar diantara kolagen dan fibrosit yang mulai terbentuk dalam tahapan penyembuhan.

Kondisi DM akan mengakibatkan sel imun tidak berfungsi sebagaimana mestinya, hal ini juga berdampak pada terhambatnya proses penyembuhan. Tahap inflamasi dalam proses penyembuhan, akan berlangsung kronis dimana terjadi peningkatan mediator proinflamatori dan menurunnya proliferasi fibroblas sebagai faktor kunci pada tahap pembentukan jaringan granulasi, yang berfungsi menjaga kekuatan jaringan pada tahap akhir penyembuhan (remodeling). ${ }^{31,32}$ Matriks metaloproteinase (MMP) dalam hal ini MMP-9 disintesis oleh makrofag dan komponen luka (fibroblas, sel epitel), dalam bentuk inaktif.

\section{KESIMPULAN}

Pada penelitian ini $\mathrm{ZnSO}_{4} 1 \%$ terbukti mampu meningkatkan jumlah fibroblas dan menurunkan ekspresi MMP-9 pada penyembuhan ulkus traumatikus, melitus, sehingga mempercepat penyembuhan ulkus traumatikus dengan kondisi diabetes melitus.

\section{SARAN}

Diperlukan penelitian lebih lanjut, pengaruh $\mathrm{ZnSO} 41 \%$ dalam mempercepat penyembuhan ulkus di rongga mulut terhadap komponen penyembuhan yang lain seperti MMP2 dan MMP-8 pada kondisi Diabetes Melitus.

\section{DAFTAR PUSTAKA}

1. Perkeni. Pengelolaan dan pencegahan diabetes melitus di Indonesia. Jakarta. 2011; hal. 23

2. DepKes RI. Pedoman pengendalian diabetes melitus dan penyakit metabolik. Dirjen Pengendalian Penyakit dan Penyehatan Lingkungan. Jakarta. 2008; Hal 45

3. DepKes RI. Diabeles Melitus, Dirjen Pengendalian Penyakit dan Penyehatan Lingkungan. Jakarta. 2012; Hal 58

4. Cotran R, Kumar V, and Robbins $S$. Pathologic basis of disease. $9^{\text {th }}$ ed. Philadelphia, PA. Saunders Elsevier. 2015; 69-110, 1105.

5. Al-Maskari AY, Al-Maskari M, Al-Sudairy S. Oral manifestation and complications of diabetes mellitus;a review. SQUMed Journal 2010; 11(2): 179-86.

6. Bastos AS, Leite ARP, Spin-Neto R, Nassar PO, Massucato EMS, Orrico SRP. Diabetes mellitus and oral mucosa alterations: prevalence and risk factors. Diabetes research and clinical practice. 2011; 100-5.

7. Cassetari LL, Dias PCR, Lucchesi AN, Ferras DAM, Spadella CT. Zinc sulphate 
administered by trandermal iontophoresis improves breaking strength of surgical wounds in skin of alloxan-induced diabetic rats. Original article wound healing. 2013; 28(8): 601-13.

8. Larjava H. Oral wound healing; cell biology and clinical management. Wiley-Blackwell Canada publising. 2012; 9-49.

9. Mallefet $P$ and Dweck AC. Mechanism involved in wound healing. The biomedical sciences. 2008; 609-14.

10. Masir O, Manjas M, Putra AE, Agus S. Pengaruh cairan cultur filtrate fibroblast (cff) terhadap penyembuhan luka; penelitian eksperimental pada rattus novergicus galur wistar. Jurnal kesehatan andalas. 2012; 1(3): 112-7.

11. Sekhon B.S. Matrix metalloproteinases-an overview. Research and report in biology. 2010; 1: 1-20.

12. Rovensky Y.A. chapter 2 The extracellular matrix: Adhesive interactions in normal and transformed cells. Springer sciences. 2011; 7-14.

13. Schifter $M$, McLean $M$, Akintoye S.O. Disorder of the endocrine system and metabolism. Burkett's oral medicine $12^{\text {th }}$ ed. People's publishing house-USA. 2015; 5679.

14. Borkow G. Copper's role in wound healing: review of literature. Better health through technology. 2014; 1-13.

15. Kim J and Lee S. Effects of zinc supplementation on insulin resistance and metabolic risk factors in obese Korean women. Nutrition research and parctice. 2012; 6(3): 221-5.

16. Akbar MS, Nurwati D, Tantiana. Efek pemberian ZnSO4 terhadap percepatan penyembuhan luka pencabutan gigi (penelitian eksperimental laboratorik pada tikus wistar). Universitas Airlangga. Surabaya. 2011; 2-3.

17. Porter S. The role of the fibroblast in wound contraction and healing. Wound healing science vol. 2007; 3(1): 33-5.

18. Delong L, Burkhart NW. General and oral pathology for the dental hygienist. Wolters Kluwer health. Lippincott Williams \& Wilkins. 2008; 70-3.

19. Jaafar SE. Wound Healing as Well as Fibroblasts and Neutrophil Numbers in a Skin Exposed to Infrared and Electrical Stimulation. Journal of Kirkuk University Scientific Studies. 2011; 6(2).

20. McDougall M, Dallon J, Sheratt J, Maini P. Fibroblast migration and collagen deposition during dermal wound healing: mathematical modelling and clinical implications. Phil. Trans. R. Soc. 2006; 1385-405.

21. Olczyk P, Mencner L, Komosinska-Vassev K. The role of the extracelluler matrix components in cutaneous wound healing. Hindawi pub. corp. 2014. http://dx.doi.org/10.1155/2014/747584 accesed february 20,2014.

22. Suryadi IA, Asmarajaya AAGN, Maliawan S. Proses penyembuhan dan penanganan luka. Fakultas kedokteran universitas udayana/ 
rumah sakit umum pusat sanglah denpasar. 2010.

23. Varun BR, Nair BJ, Sivakumar TT, Joseph AP. Matrixs metalloproteinases and their role in oral diseases: a review. Oral \& maxillofacial pathology journal. 2012; 3(1): 186-200.

24. Kuroki S, Yokoo S, Terashi H, Hasegawa M, and Komori T. Epithelialization in Oral Mucous Wound Healing in Terms of Energy Metabolism. Kobe J. Med. Sci. Vol. 2009; 55(2): 5-15.

25. Lobmann R, Ambrosch A, Schultz G, Waldmann K, Schiweek S, Lehnert $H$. Expression of MMPs and their inhibitor in the wound of diabetic and non-diabetic patients. Diabetologica. 2002; 45: 1011-16.

26. McLennan SV, Min D, Yue DK. Matrix metalloproteinases and their roles in poor wound healing in diabetes. Wound practice and research vol. 2008; 16(3): 116-23.

27. Jayawardena R, Ranasinghe P, Galappatthy P, Malkanthi RLDK, Consytantine GR, Katulanda P. Effects of zinc supplementation on diabetes mellitus: asystematic review and meta-analysis. Diabetology and Metabolic syndrome. BioMed Central. 2012; 4(13): 111.

28. Budiasih KS. Interferensi Ion Cd (II) dan $\mathrm{Hg}(\mathrm{II})$ terhadap biofungsi persenyawaan Zn(II) pada tubuh manusia. Prosiding seminar nasional penelitian, pendidikan dan penerapan MIPA Fakultas MIPA, Universitas Negeri Yogyakarta. 2011.p 1-9.

29. Nygaard SB, Larsen A, Knuhtsen A, Rungby J, Smidt K. Effects of zinc supplementations and zinc chelation on in vitro beta-cell function in INS-1E cells. BioMed Central. 2014; 7(84): 3-12.

30. Peake MA, Caley M, Giles P., Wall I. Enoch S, Davies L., Kipling D, Thomas D, Stephens P. Identification of a transcriptional signature for the wound healing continuum. Wound Rep Reg. 2013; 22: 399-405.

31. Ranasinghe $P$, Pigera $S$, Galappathy $P$, Katulanda P, Constantine G.R. Zinc and diabetes mellitus: understanding molecular mechanism and clinical implications. Journal of pharmaceutical sciences. 2015; 23(44): 113.

32. Tellechea A, Leal E, Veves A, Carvalho E. Inflammatory and angiogenic abnormalities in diabetic wound healing: role of neuropeptides and therapeutic perspectives. The open circulation and vascular journals. 2010; 3: 43-55. 